\title{
Integration Between Arbuscular Mycorrhizal Fungi, Bacterial and Fungal Bioagents for Controlling Rice Brown Spot Disease
}

\author{
Saleh, M.M. (D) and El-Akshar, Y.S.
}

Received: 20 October 2020 / Accepted: 14 December 2020 / Published online: 30 December 2020.

C) Egyptian Phytopathological Society 2020

\begin{abstract}
The main purpose of this work was to test the efficiency of Arbuscular mycorrhizal fungi (AMF) in inducing systemic acquired resistance against rice brown spot disease alone or in combinations with the bioagents, Pseudomonas fluorescens (Pf) and Trichoderma viride (T.v.). In vitro test showed inhibition of $52.85 \%$ and $57.14 \%$, respectively for the two selected bioagents with deformation and lysis for the pathogen spores. Under greenhouse conditions, the mixture of $\mathrm{AMF}+\mathrm{Tv}$ and $\mathrm{AMF}+\mathrm{Pf}+\mathrm{Tv}$, showed the highest efficiency in reducing the disease incidence after the fungicide treatment, whereas they achieved 65.60 and $48.40 \%$, respectively. Field trials at two locations showed potentiality of AMF combined with the other bioagents in decreasing the percentages of disease incidence and severity. Also, the applied treatment increased the plant growth parameters, i.e., chlorophyll content, plant height and yield. Microscopic examination for rice plant roots showed colonization structures of AMF. Also, Pathogenesis related proteins had been defined.
\end{abstract}

Key words: Rice brown spot, Arbuscular mycorrhizal fungi, bioagents, induced resistance, enzymes

*Correspondence: Saleh, M.M.

E-mail: habebanna@yahoo.com

\section{Mona M. Saleh}

(iD) https://orcid.org/0000-0002-3676-7516

Plant Pathology Research Institute, Agricultural Research Center, 12619, Giza, Egypt.

\section{Yasser S. El-Akshar}

(iD) https://orcid.org/0000-0001-8409-9965

Soils, Water and Environment Research Institute, Agricultural Research Center, 12619, Giza, Egypt.

\section{INTRODUCTION}

Rice brown spot disease (RBS) caused by Cochliobolus miyabeanus (Ito and Kuribayashi Drechsler ex Dastur) Shoem Anamorph: Bipolaris oryzae (Breda de Haan), is one of the major rice diseases and is a world- wide distributed (Devi and Chhetry, 2013) causing seedling blight when infected seeds are used. So, seedlings or older plants become weak and in case of grain infection, grain quality and weight are decreased (Iqbal et al., 2015). RBS occurs especially in poor fields that suffer from scarce of water supply or irrigated with mixed water (fresh water + drainage water). Also, it is often associated with imbalances in mineral nutrition of plants, especially nitrogen element (Carvalho et al., 2010). Severe infection may cause losses of $26-52 \%$ (Chakrabarti, 2001). It is remarkable to point out to the great Bengal famine in 1943 as a result of RBS epidemiological, causing up to $90 \%$ loss in rice yield (Padmanabhan, 1973). Many protective and curative trials including agricultural methods or usage of bio and chemical substances have been investigated to control the disease. Seed treatment started very early by Nisikado and Miyake (1922), who found that treating rice seeds by hot water or $\mathrm{CuSO}_{4}$ was useful in reducing seedlings damage. Since then many workers investigated seed treatment by many substances whether chemical or bio ones, while fungicidal field spraying has been tried to prevent secondary air-borne infection (Ou, 1985). To keep our environment less contaminated with fungicides, less toxic to living organisms and to decrease costs to growers, we performed this study to test an ecofriendly and good alternative method than chemical one for clean agriculture.

Different bioagents, i.e., Arbuscular Mycorrhizae Fungi (AMF), Trichoderma viride and Pseudomonas fluorescens have been tested. AMF are known to have an indirect effect on plant disease control whether on soil borne or foliar diseases (Hodge et al., 2003). They are known to present various benefits to plants, including enhanced nutrients availability to plants and their uptake (particularly $\mathrm{P}$ ), increased water uptake, improved biotic and abiotic stress tolerance and improved soil structure, thus significantly contributing to control diseases (Addo et al., 2020). Trichoderma species are able to colonize the root surface and rhizosphere when applied as seed treatment, protecting them from fungal invasion. Also, Pseudomonas fluorescens has efficiency in controlling RBS disease and seed discoloration by 28.18 and $33.33 \%$, respectively 
(Balgude et al., 2017). To our knowledge, there is no available report on comparing the usage of $\mathrm{AMF}$ and other bioagents as rice seed dressing and their potentiality against rice brown spot disease in Egypt, in addition to their effect on growth parameters. Therefore, this study was performed to evaluate the potential effect of integration between AMF with selected bioagents, $P$. fluorescens and $T$. viride against RBS disease incidence and severity.

\section{MATERIALS AND METHODS}

The phytopathogen and antagonistic isolates:

Bipolaris oryzae was isolated from naturally infected leaves showing typical symptoms of brown spot disease according to Gomathinayagam et al., 2012. An active strain of $P$. fluorescens and inocula of Arbuscular Mycorrhizae Fungi (AMF) were kindly supplied by Department of Agric. Microbiology, Soils, Water and Environment Research Institute (SWERI), ARC, Giza, Egypt. While an isolate of Trichoderma viride was obtained from previous work of Saleh, 2012. This isolate was identified at Laboratory of Mycology, Plant Pathology Institute, Agricultural Research Center, Giza, Egypt.

In vitro, antagonistic action of $P$. fluorescens and $T$. viride against Bipolaris oryzae:

Plates of $9 \mathrm{~cm}$ containing PDA medium were inoculated with discs (5 $\mathrm{mm}$ in diameter) taken from 7 days old culture of Bipolaris oryzae on one side. Two days later, by a sterilized inoculation needle, a loopful of actively $P$. fluorescens growing culture $\left(48 \mathrm{hrs}\right.$ at $\left.28^{\circ} \mathrm{C}\right)$ was streaked in a gentle three $\mathrm{cm}$ long at the opposite side of the same plate. Experiment was made in three replicates. Plates free from bacterium were left as control. Plates were incubated at $28 \pm 2{ }^{\circ} \mathrm{C}$ for five days later. Then diameter of inhibition zone was recorded, and the relative power of antibiosis (RPA) was estimated through the ratio as described by Saleh (2012) as follows:

$$
\mathrm{RPA}=\frac{Z}{C}
$$

Where:

$\mathrm{Z}=$ Diameter of inhibition zone.

$\mathrm{C}=$ Diameter of spotted antagonistic isolate.

For $T$. viride, Petri dishes of $9 \mathrm{~cm}$ containing PDA medium were inoculated with discs of 6 $\mathrm{mm}$ diameter taken from the edge of expanding colonies of Bipolaris oryzae on one side. After two days, one disc of $T$. viride growth $(6 \mathrm{~mm}$ diameter) was cultured onto the medium on the opposite side of the same plate. Plates containing the pathogen only were included as a check treatment. Three replicates were used for each treatment. Paired cultures were incubated at $28 \pm 2^{\circ} \mathrm{C}$ till the growth of control treatment filled the whole plate surface. As a result of the antagonistic effect inhibition\% of the pathogen mycelial, growth was determined according to Khalili et al. (2012) as follows:

$$
\text { Inhibition } \%=\frac{(\mathrm{R} 2-\mathrm{R} 1)}{\mathrm{R} 2} \times 100
$$

Where:

$\mathrm{R} 2$ = the average of growth diameter of the pathogen in control plates and

$\mathrm{R} 1$ = the average of mycelial growth of the pathogen in treated plates.

Mycelial growth samples (pathogen hyphae), cut from the edge of interaction region in dual culture tests (7 days), were fixed on slide glass to observe any changes in the pathogen structures under an inverted Binocular Light Microscope (Labomed, 40x)

\section{Preparation of the pathogenic fungi:}

The phytopathogen was cultured in Petri dishes containing PDA medium and incubated at $28 \pm 2{ }^{\circ} \mathrm{C}$ until full growth. To enhance sporulation, plates were exposed to continuous fluorescent light for two days. To prepare inoculum of spore suspension, $10 \mathrm{ml}$ sterilized water were added in each dish, mycelia mats were gently scraped by a spatula and filtered through cheese cloth. Spore suspension was adjusted to be $10^{5}$ (Khalili et al., 2012).

\section{1- Preparation of biocontrol agents:}

\section{A) Arbuscular Mycorrhizal Fungi inoculum}

\section{(AMF):}

Inoculum of Arbuscular Mycorrhizae Fungi (AMF) was prepared according to the method of Massoud (2005) in order to be used throughout the current study.

\section{B) Pseudomonas fluorescens inoculum:}

A strain of $P$. fluorescens was cultured and maintained on King's B medium (King et al., 1954) at $28 \pm 2^{\circ} \mathrm{C}$ for 2 days. The biomass of $P$. fluorescens was prepared by inoculating a disc of a pre-culture of $P$. fluorescens in a $500 \mathrm{ml}$ Erlenmeyer flask containing $200 \mathrm{ml}$ of King's broth medium, then incubated on a rotatory shaking incubator $(120 \mathrm{rpm})$ for 72 hours at $28 \pm 2^{\circ} \mathrm{C}$. The density of bacterial cell culture was adjusted to be $10^{8} \quad \mathrm{CFU} / \mathrm{ml}$ using hemocytometer slide.

C) Preparation of $T$. viride:

Inoculum of Trichoderma viride was prepared by growing $T$. viride in conical flasks containing $500 \mathrm{ml}$ PD broth (PDB) medium and incubated for 15 days. The fungal mass was 
blended, and concentration was adjusted to be $10^{8}$ spore/ml (El-Gremi and Saleh, 2013).

2- Rice grains treatment with bioagents inoculum:

Each inoculum of the three bioagents biomass (AMF, P. fluorescens and T. viride) was applied as seed dressing according to Saleh, (2002) as follows: inoculum of AM-fungi was added to peat at the rate of $1 / 1 \mathrm{~g}$ (peat was wetted with water before mixing). While the cell suspension of the antagonistic isolates $(P$. fluorescens and $T$. viride) containing $10^{8}$ $\mathrm{CFU} / \mathrm{ml}$ of the bacterium or $10^{8} \mathrm{spore} / \mathrm{ml}$ of the fungus was added to peat at the rate of $1 \mathrm{ml} / \mathrm{g}$ peat, well mixed and left at room temperature for $48 \mathrm{hr}$ before seed dressing. Rice grains soaked for $24 \mathrm{~h}$ in water were wetted by $10 \%$ Arabic gum water solution and then dressed with the prepared antagonistic peat at rat of $1 \mathrm{~g} / \mathrm{g}$ grains. Treated grains were then ready for sowing.

Plant materials:

Rice grains cv. Giza 177 was used in this experiment. Rice grains were surface sterilized with Sodium Hypochlorite (5\%) for $5 \mathrm{~min}$., washed several times with sterile distilled water and then were air dried.

\section{Greenhouse experiment:}

A pot experiment was performed at the greenhouse of Rice Pathology Research Dept., Rice Research and Training Center (RRTC), Sakha Agricultural Research Station. Seed dressing method was applied according to Saleh, 2002. Pots with $15 \mathrm{~cm}$ diameter were filled with clay loam soil, planted with the susceptible rice cultivar (Giza177) and arranged according to the following treatments: 1. Arbuscular Mycorrhizal Fungi (AMF); 2. P. fluorescens (P.f) $\left(10^{8} \mathrm{CFU} /\right.$ $\mathrm{ml})$; 3. T. viride (T.v.) $\left(10^{8}\right.$ spore/ ml); 4. AMF + P.f; 5. AMF + T.V.; 6. P.f + T.V.; 7. AMF + P.f + T.V.; 8. Fungicide Del cup (Copper sulphate pentahydrate) and 9. Check treatment (control). The used fungicide Del cup ( $\left.\mathrm{CuSO}_{4} .5 \mathrm{H}_{2} \mathrm{O}\right) 6 \%$ $\mathrm{L} / \mathrm{fed}$ was sprayed at a rate equivalent to $5 \mathrm{~cm} /$ L. After 21 day of sowing, seedlings were sprayed with the pathogen spore suspension $\left(10^{5}\right.$ spores $\left./ \mathrm{ml}\right)$. All treated pots were kept in a moistened dark chamber with $98-100 \%$ relative humidity for 24 hours and then transferred out under sprinkler with half an hour interval. A completely randomized design (CRD) with three replicates for each treatment was conducted. Data were recorded 5 days after inoculation, a randomly 25 leaves were selected per pot to calculate disease incidence $\%$ and disease severity.

\section{Field trail:}

The same previous design of treatments was conducted at two locations, Sakha and Gemmiza farms of Agricultural Research Stations, at the same season of 2017. Grains of Giza 177 rice cultivar were directly planted after being dressed with the different bioagents (as mentioned before) according to Saleh (2002). Three plots $\left(1 \mathrm{~m}^{2} / \mathrm{plot}\right)$ as replicates were used for each treatment. A randomized complete blocks design was conducted. Percentage of disease incidence and severity as well as some plant growth parameters including chlorophyll content, plant height and yield (g) were recorded.

\section{Assessment of disease incidence and severity of brown spot:}

Percentages of incidence and severity of brown spot were recorded under artificial and natural conditions after 30 and 70 days of cultivation, respectively. Ten hills were randomly selected from each plot and data were collected on number of tillers/hill, number of diseased tillers/hill and number of spots/hill. Percentage of disease incidence and severity were assessed according to Rashed et al. (2002). Disease severity was scored according to the Standard Evaluation System for rice (IRRI, 2002) as following:

1 - Disease incidence $(\%)=$

No. of diseased leaves or tillers

No. of total examined leaves or $\times 100$ tillers

2 - Disease severity $=$

Sum of total ratings
Total no. of observed leaves or
tillers $\times$ Maximum grade in the scale

On the other hand, efficacy $\%$ for each biocontrol agent severity was calculated according to Muhanna et al. (2016) as follows:

$$
\text { Efficacy } \%=\frac{\text { Control }- \text { treatment }}{\text { Control }} \times 100
$$

\section{AMF microscopical examination:}

A sample of Giza 177 rice cultivar roots was cut into pieces of $1 \mathrm{~cm}$. long. The pieces were immersed in a $100 \mathrm{ml}$ flask containing $\mathrm{KOH}$ $10 \%$ solution $\mathrm{w} / \mathrm{v}$. Then flasks containing roots were sterilized in an autoclave for 15-20 minutes at $121^{\circ} \mathrm{C}$. Sterilized root pieces were then washed with distilled water several times before transferring them into the staining solution. Root pieces were stained with ink and vinegar according to Vierheilig et al. (1998) and examined under stereomicroscope. 


\section{Assay of enzymes activity:}

To determine the defense related enzyme activity of rice plants against Bipolaris oryzae, activities of Peroxidase (POX), Poly phenoloxidase (PPO) and Catalase (CT) were assessed according to methods described by Allam and Hollis (1972), Maxwell and Bateman (1967) and Chandlee and Scandalios (1984), respectively. Activities were measured after 24, 48 and 72 hours (h) of the pathogen inoculation of rice plants grown under greenhouse conditions.

\section{Statistical analysis:}

Means were compared using multiple range tests according to Duncan (1955) using computer program COSTAT.

\section{RESULTS}

Effect of Pseudomonas fluorescens and Trichoderma viride on the pathogen fungal growth:

Data presented in Table (1) show the ability of Pseudomonas fluorescens and Trichoderma

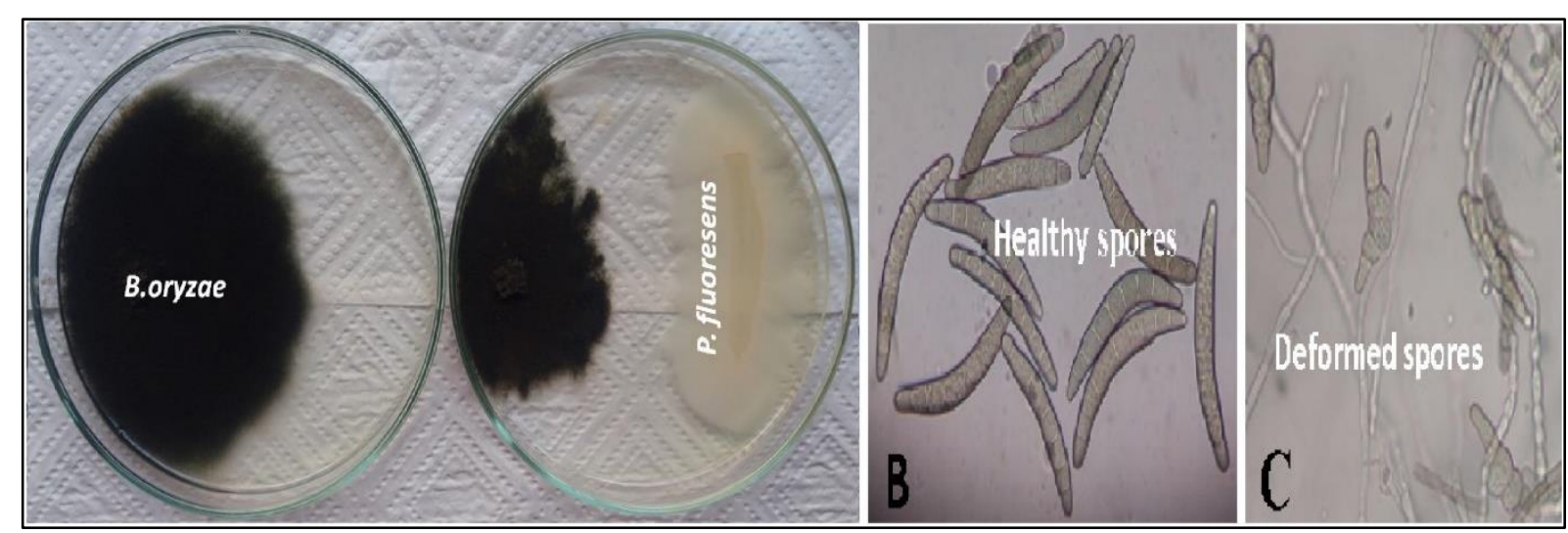

Fig (1): Effect of Pseudomonas fluorescens against B. oryzae in vitro (B \& C, 40X).
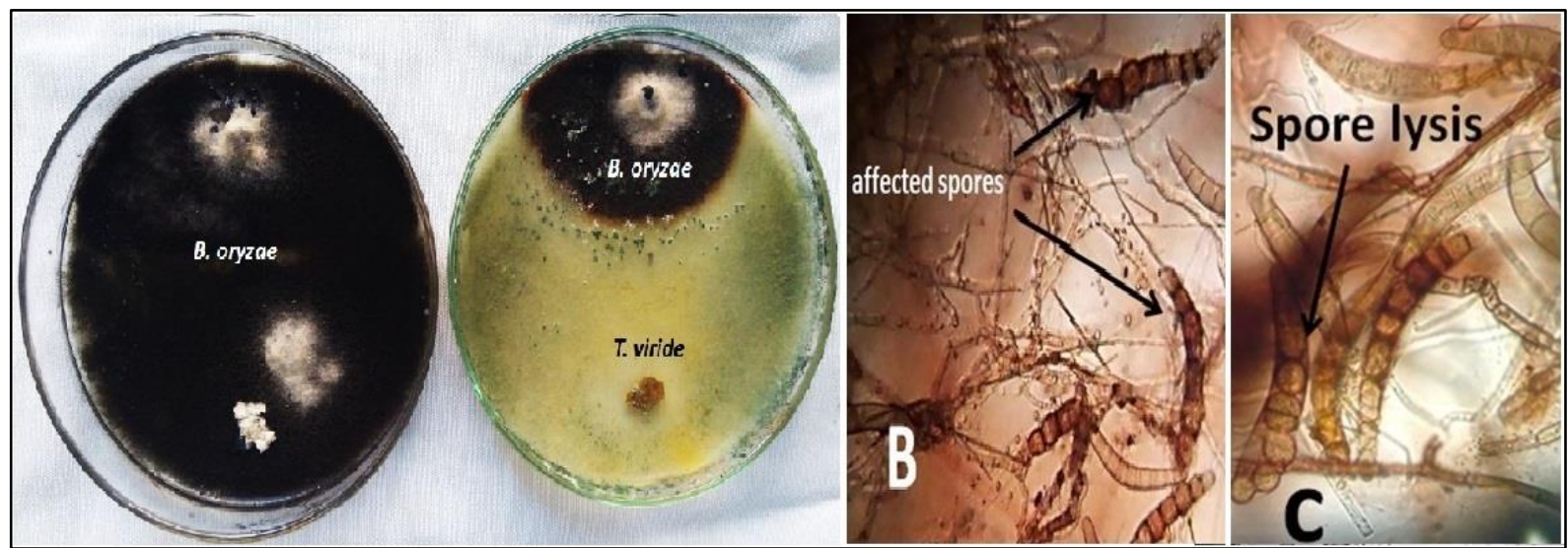

Fig (2): Effect of Trichoderma viride against $B$. oryzae in vitro (B \& $\mathrm{C}, 40 \mathrm{X})$.

\section{Greenhouse experiment:}

The results of rice seed dressed with Arbuscular Mycorrhizal Fungi (AMF), $P$. fluorescens (P.f) and T. viride (T.v) viride to inhibit the mycelial growth of Bipolaris oryzae resulting in 52.85 and $57.14 \%$ inhibition in mycelial growth, respectively compared with the check treatment. In addition, the two bioagents caused deformation and lysis to the pathogen spores compared with the healthy one (Fig $1 \& 2$ ).

Table (1): In vitro, antagonistic effect of Pseudomonas fluorescens and Trichoderma viridi against Bipolaris oryzae mycelial growth

\begin{tabular}{lcc}
\hline \multirow{2}{*}{ Treatment } & $\begin{array}{c}\text { Mycelial } \\
\text { growth } \\
(\mathrm{mm})\end{array}$ & $\begin{array}{c}\text { Growth } \\
\text { inhibition } \\
\%\end{array}$ \\
\hline $\begin{array}{lcc}\text { Pseudomonas fluorescens } \\
\text { Trichoderma viride }\end{array}$ & $3.3 \mathrm{~b}$ & 52.85 \\
\cline { 2 - 3 } Control & $3 \mathrm{c}$ & 57.14 \\
\cline { 2 - 3 } & $7 \mathrm{a}$ & - \\
\hline
\end{tabular}

Means followed by the same letter (s) within the column are not significantly different $(\mathrm{P} \leq$ $0.05)$. 
had different efficiency for reducing the brown spot disease incidence compared with the untreated one. The chemical fungicide Del cup 6\% revealed the lowest disease incidence \%, disease severity and the highest efficiency. The corresponding percentages are 3.33, 10.66 and $79.62 \%$, respectively. While significant decreases in both disease incidence and severity, being $6 \%$ and $18 \%$ with increase in efficiency $(65.60 \%)$ when seeds were coated with the mixture of the two bioagents, AMF $+\mathrm{T}$. viride, followed by the two same significant treatments; AMF alone, that recorded low disease incidence, severity and high efficiency being 8.33, 29 and $44.58 \%$, respectively and the mixture of AMF, $P$. fluorescens and $T$. viride which recorded $7.66 \% \quad 27$ and $48.40 \%$, respectively. Whereas, the treatment of $T$. viride alone achieved disease incidence, severity and efficiency of $9.33,31.33$ and $40.12 \%$, respectively. The bioagent and fungicide treatments achieved lower disease severity and higher efficiency than the check which recorded the highest disease incidence and severity, being 13.33 and $52.33 \%$, respectively.

Table (2): Effect of seed dressing with Arbuscular mycorrhizal fungi (AMF), $P$. fluorescens (P.f.) and T. viride (T.v.) as bioagents on decreasing rice brown spot disease under greenhouse conditions

\begin{tabular}{ll|c|cc}
\hline No. & Treatment & $\begin{array}{c}\text { disease } \\
\text { incidence } \\
\%\end{array}$ & $\begin{array}{c}\text { disease } \\
\text { severity } \\
\%\end{array}$ & $\begin{array}{c}\% \\
\text { Efficacy }\end{array}$ \\
\hline 1 & AMF & $8.33 \mathrm{~d}$ & $29.00 \mathrm{e}$ & 44.58 \\
\hline 2 & P.f. & $11 \mathrm{~b}$ & $40.00 \mathrm{~b}$ & 23.56 \\
3 & T.v. & $9.33 \mathrm{c}$ & $31.33 \mathrm{~d}$ & 40.12 \\
\hline 4 & AMF+ P.f. & $11.00 \mathrm{~b}$ & $41.00 \mathrm{~b}$ & 21.65 \\
\hline 5 & AMF+ T.v. & $6.00 \mathrm{e}$ & $18.00 \mathrm{~g}$ & 65.60 \\
\hline 6 & Pf+ T.v. & $10.33 \mathrm{~b}$ & $35.33 \mathrm{c}$ & 32.48 \\
\hline 7 & AMF+ P.f.+ T.v. & $7.66 \mathrm{~d}$ & $27.00 \mathrm{f}$ & 48.40 \\
\hline 8 & Del cup & $3.33 \mathrm{f}$ & $10.66 \mathrm{~h}$ & 79.62 \\
\cline { 2 - 5 } 9 & Control & $13.33 \mathrm{a}$ & $52.33 \mathrm{a}$ & - \\
\hline
\end{tabular}

Means followed by the same letter (s) within the column are not significantly different $(\mathrm{P} \leq 0.05)$.

\section{Field trails:}

Data presented in Tables (3 and 4) show that all bioagent treatments or their combinations were efficient in reducing disease incidence and severity compared with check treatment and the fungicide treatment. The bioagent treatments exceeded Del cup fungicide in reducing disease incidence and severity \% at Sakha location in contrary to Gemmiza location, where the fungicide was the best in achieving the least disease incidence and disease severity \%. At Sakha location, Table (3) show that dressing rice seeds with $\mathrm{AMF}+$ T.v. treatment showed the lowest disease incidence and severity $(13.33 \%$ \& $21.33 \%$, respectively), followed by the treatment of T.v. only $(18.66 \%$ \& $38.66 \%$, respectively) and the AMF + P.f. treatment (18.66\% \& $46.66 \%$, respectively). Whereas the fungicide treatment recorded the highest disease incidence \% and severity (30.66 and $69.33 \%$, respectively). Data also showed that there were no significant differences among all treatments in chlorophyll content. Del cup fungicide treatment gave the highest plant height $(111.44 \mathrm{~cm})$ followed by treatments with AMF only $(100.44 \mathrm{~cm})$, P.f.+ T.v. $(98.77 \mathrm{~cm})$ and the mixture of AMF + P.f. + T.v. $(99.44 \mathrm{~cm})$, respectively, the last two treatments were not significantly different. Also, the fungicide treatment achieved the highest yield $\left(958.33 \mathrm{~g} / \mathrm{m}^{2}\right)$ followed by treatents with AMF $\left(886.66 \mathrm{~g} / \mathrm{m}^{2}\right)$, AMF + P.f. + T.v. $\left(846.66 \mathrm{~g} / \mathrm{m}^{2}\right)$ without significant difference than T.v. (843.33 $\mathrm{g} / \mathrm{m}^{2}$ ).

At Gemmiza location, data presented in Table (4) show the efficiency of all the bioagent treatments or their combinations after Del cup fungicide treatment. As Del cup fungicide recorded the least disease incidence and severity (18\% \& 22\%, respectively), followed by AMF treatment (24\% \& 52\%, respectively) and AMF + P.f. (30.66\% \& 50.66\%, respectively). Significant differences were found between all treatments in chlorophyll content. Dressing seeds with the mixture of AMF + P.f. + T.v. and treatment of P.f. only gave the highest chlorophyll content being, 39.93 \& 39.73, respectively followed by the fungicide (38.83). Also, treatment with AMF treatment was equal with Del cup fungicide in plant height as they recorded the highest length $(97.22 \mathrm{~cm}$ $\& 96.33 \mathrm{~cm}$, respectively) followed by AMF + T.v. $(93.11 \mathrm{~cm})$ and $\mathrm{AMF}+$ P.f. $(91.22 \mathrm{~cm})$, respectively. All the treatments were effective than the check in plant yield and significant differences were found. The treatment of T.v. was the best achieving $982 \mathrm{~g} / \mathrm{m}^{2}$ followed by $\mathrm{AMF}+$ P.f. + T.v. $\left(900 \mathrm{~g} / \mathrm{m}^{2}\right)$ and P.f. + T.v. $\left(865 \mathrm{~g} / \mathrm{m}^{2}\right)$. Del cup fungicide showed no significant differences with $\mathrm{AMF}+$ T.v. treatment recording $830 \quad \& 825 \quad \mathrm{~g} / \mathrm{m}^{2}$, respectively. 
Table (3): Effect of seed dressing with Arbuscular mycorrhizal fungi (AMF), P. fluorescens (P.f.) and $T$. viride (T.v.) as bioagents on decreasing rice brown spot disease at Sakha location

\begin{tabular}{|c|c|c|c|c|c|c|}
\hline No. & Treatment & $\begin{array}{c}\text { Disease } \\
\text { incidence } \%\end{array}$ & $\begin{array}{c}\text { Disease } \\
\text { severity } \% \\
\end{array}$ & $\begin{array}{c}\text { Chlorophill } \\
\text { (SPAD) }\end{array}$ & $\begin{array}{c}\text { Plant height } \\
(\mathrm{cm})\end{array}$ & $\begin{array}{c}\text { Yield } \\
(\mathrm{g})\end{array}$ \\
\hline 1 & AMF & $25.33 \mathrm{e}$ & $40 \mathrm{f}$ & $45.8 \mathrm{ab}$ & $100.44 \mathrm{~b}$ & $886.66 \mathrm{~b}$ \\
\hline 2 & P.f. & $25.33 \mathrm{e}$ & $46.66 \mathrm{~d}$ & $43.2 \mathrm{~b}$ & $95.99 \mathrm{de}$ & $760.00 \mathrm{f}$ \\
\hline 3 & T.v. & $18.66 \mathrm{f}$ & $38.66 \mathrm{~g}$ & $45.23 \mathrm{ab}$ & $95.11 \mathrm{e}$ & $843.33 \mathrm{c}$ \\
\hline 4 & $\mathrm{AMF}+$ P.f. & $18.66 \mathrm{f}$ & $46.66 \mathrm{~d}$ & $46.2 \mathrm{ab}$ & $98.11 \mathrm{bcd}$ & $790 \mathrm{e}$ \\
\hline 5 & $\mathrm{AMF}+\mathrm{T} . \mathrm{v}$ & $13.33 \mathrm{~g}$ & $21.33 \mathrm{~h}$ & $44.3 \mathrm{ab}$ & 97.22 cde & $820.00 \mathrm{~d}$ \\
\hline 6 & P.f. + T.v. & $28 \mathrm{~d}$ & $42.66 \mathrm{e}$ & $43.2 \mathrm{~b}$ & $98.77 \mathrm{bc}$ & $820.00 \mathrm{~d}$ \\
\hline 7 & AMF + P.f.+ T.v. & $29.33 c$ & $52 \mathrm{c}$ & $46.7 \mathrm{a}$ & $99.44 \mathrm{bc}$ & $846.66 \mathrm{c}$ \\
\hline 8 & Del cup & $30.66 \mathrm{~b}$ & $69.33 \mathrm{~b}$ & $46.53 \mathrm{ab}$ & $111.44 \mathrm{a}$ & $958.33 \mathrm{a}$ \\
\hline 9 & Control & $37.33 \mathrm{a}$ & $78.66 \mathrm{a}$ & $43.13 \mathrm{~b}$ & $92.11 \mathrm{f}$ & $756.66 \mathrm{f}$ \\
\hline
\end{tabular}

Means followed by the same letter (s) within the column are not significantly different $(\mathrm{P} \leq 0.05)$.

Table (4): Effect of seed dressing with Arbuscular mycorrhizal fungi (AMF), P. fluorescens (P.f.) and $T$. viride (T.v.) as bioagents on decreasing rice brown spot disease at Gemmiza location

\begin{tabular}{|c|c|c|c|c|c|c|}
\hline No. & Treatment & Infection $\%$ & Severity $\%$ & $\begin{array}{c}\text { Chlorophill } \\
\text { (SPAD) }\end{array}$ & $\begin{array}{c}\text { Plant height } \\
(\mathrm{cm})\end{array}$ & $\begin{array}{c}\text { Yield } \\
(\mathrm{g})\end{array}$ \\
\hline 1 & AMF & $24 \mathrm{~h}$ & $52 \mathrm{~g}$ & $38.63 \mathrm{c}$ & $97.22 \mathrm{a}$ & $801 \mathrm{e}$ \\
\hline 2 & P.f. & $40 \mathrm{e}$ & $102.66 \mathrm{e}$ & $39.73 \mathrm{ab}$ & $89.67 \mathrm{~d}$ & $805 \mathrm{e}$ \\
\hline 3 & T.v. & $36 \mathrm{f}$ & $61.33 \mathrm{f}$ & $31.50 \mathrm{e}$ & $85 \mathrm{e}$ & $982 \mathrm{a}$ \\
\hline 4 & AMF + P.f. & $30.66 \mathrm{~g}$ & $50.66 \mathrm{~h}$ & $38.63 \mathrm{c}$ & $91.22 \mathrm{c}$ & $771 \mathrm{f}$ \\
\hline 5 & $\mathrm{AMF}+\mathrm{T} . \mathrm{v}$ & $52 \mathrm{c}$ & $110.66 \mathrm{c}$ & $36.00 \mathrm{~d}$ & $93.11 \mathrm{~b}$ & $825 \mathrm{~d}$ \\
\hline 6 & P.f. + T.v. & $72 b$ & $197.33 \mathrm{a}$ & $28.56 \mathrm{f}$ & $83.44 \mathrm{f}$ & $865 \mathrm{c}$ \\
\hline 7 & AMF + P.f. + T.v. & $48 \mathrm{~d}$ & $109.33 \mathrm{~d}$ & $39.93 \mathrm{a}$ & $89.33 \mathrm{~d}$ & $900 \mathrm{~b}$ \\
\hline 8 & Del cup & $18 \mathrm{i}$ & $22 \mathrm{i}$ & $38.83 \mathrm{bc}$ & $96.33 \mathrm{a}$ & $830 \mathrm{~d}$ \\
\hline 9 & Control & $76 \mathrm{a}$ & $181.33 \mathrm{~b}$ & $36.15 \mathrm{~d}$ & $92.11 \mathrm{bc}$ & $710 \mathrm{~g}$ \\
\hline
\end{tabular}

Means followed by the same letter (s) within the column are not significantly different $(\mathrm{P} \leq 0.05)$.

AMF microscopical examination:

Staining rice roots of Giza $177 \mathrm{cv}$. showed the colonization of Arbuscular mycorrhizal
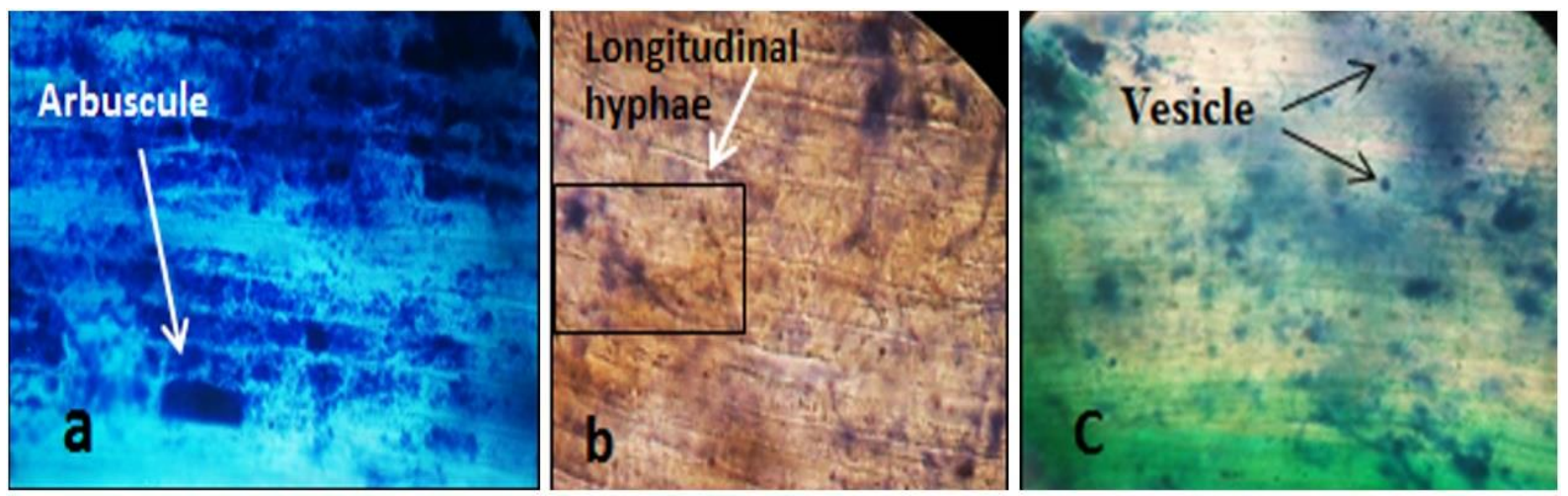

Fig (3): Light micrographs of arbuscular mycorrhizal fungi (AMF) in Giza 177 rice cultivar roots, (a) arbuscule, (b) longitudinal hyphae and (c) vesicle.

\section{Assay of enzymes:}

Data illustrated in Figure (4) show the changes in activity of peroxidase (POX) when rice plants were artificially inoculated with Bipolaris oryzae under greenhouse conditions. In all treatments POX activity was higher than in the check. Among all treatments, AMF + P.f. fungi to them. Figure (3) illustrates the presence of arbuscule, longitudinal hyphae and vesicles. 
observed at the treatment of $\mathrm{AMF}+\mathrm{Tv}$. Other treatments showed an increase in POX activity after $48 \mathrm{~h}$, then reduced after $72 \mathrm{~h}$ of inoculation. Activity of polyphenoloxidase (PPO) recorded the best after $24 \mathrm{~h}$ of inoculation at P.f. $+\mathrm{Tv}$, $\mathrm{AMF}+$ P.f. + Tv, AMF and fungicide treatments $(0.49, \quad 0.17,0.14$ and 0.14 , respectively) where AMF was similar with the fungicide (Fig. 5). After 48h and 72h, PPO activity fluctuated in all treatments, being higher than in the check. The fungicide was the only treatment that maintained stable till $72 \mathrm{~h}$ for PPO activity. Data presented in Figure (6) show that the treatments of the fungicide, AMF + P.f. + Tv, P.f. and AMF + T.v. showed the highest after $24 \mathrm{~h}$ of infection in catalase activity (160.49, 148.16, 116.79 and 104.34, respectively). While, after $48 \mathrm{~h}$ catalase activity was increased due to treatments, i.e., AMF + T.v.; T.v; AMF + P.f. + Tv and AMF + P.f. which recorded $129.22 ; 122.61 ; 97.42$ and 81.25, respectively. Also, catalase activity increased after $72 \mathrm{~h}$ in plants treated with $\mathrm{AMF}+$ Pf; P.f.; AMF + T.v. and AMF only, respectively.

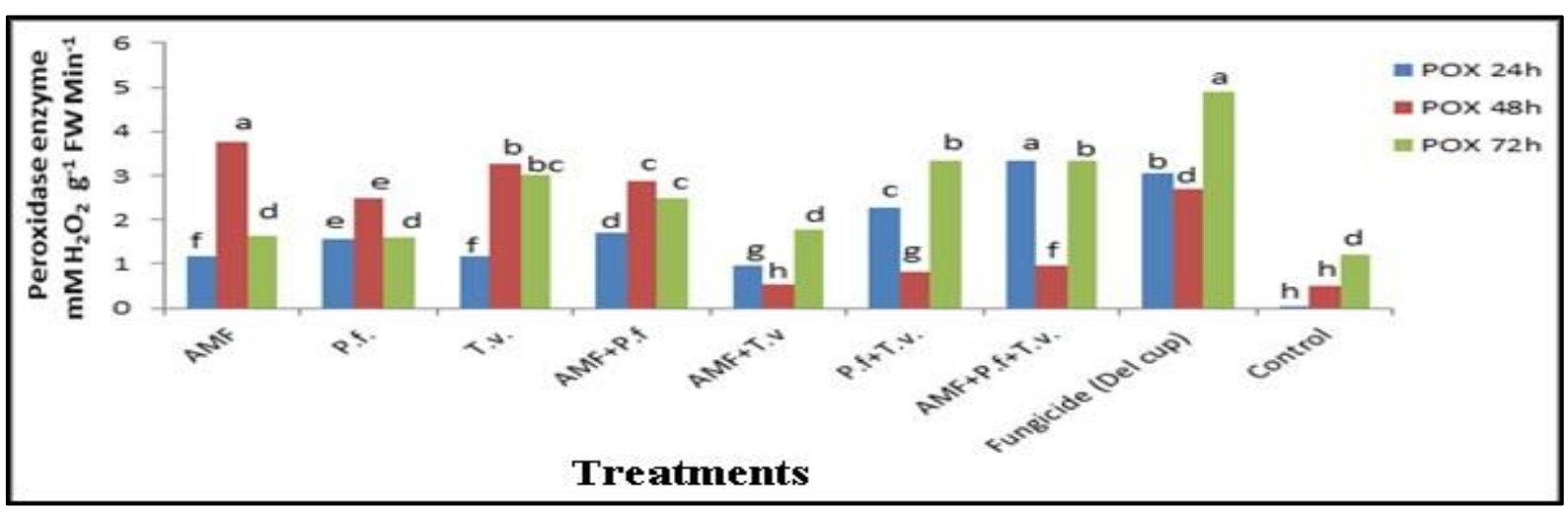

Fig (4): Changes in peroxidase activity in Giza 177 rice cultivar treated with three bio-control agents (AMF, P.f. and T.v.) and the fungicide Del-cup.

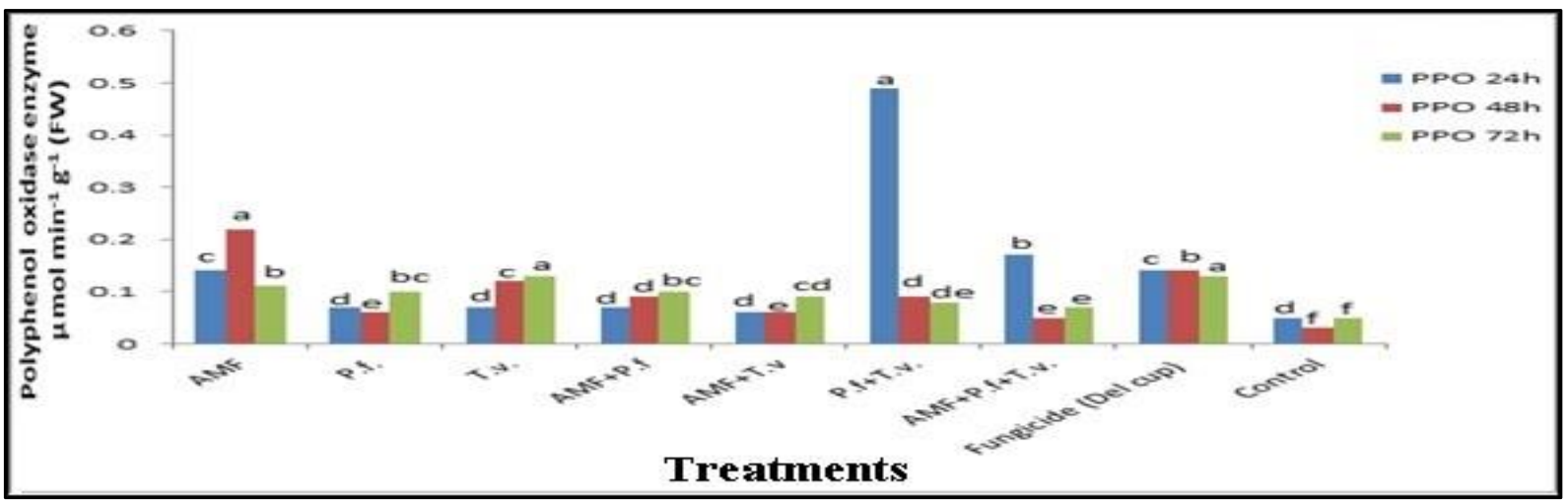

Fig (5): Changes in polyphenoloxidase activity in Giza 177 rice cultivar treated with three biocontrol agents (AMF, P.f. and T.v.) and the fungicide Del-cup

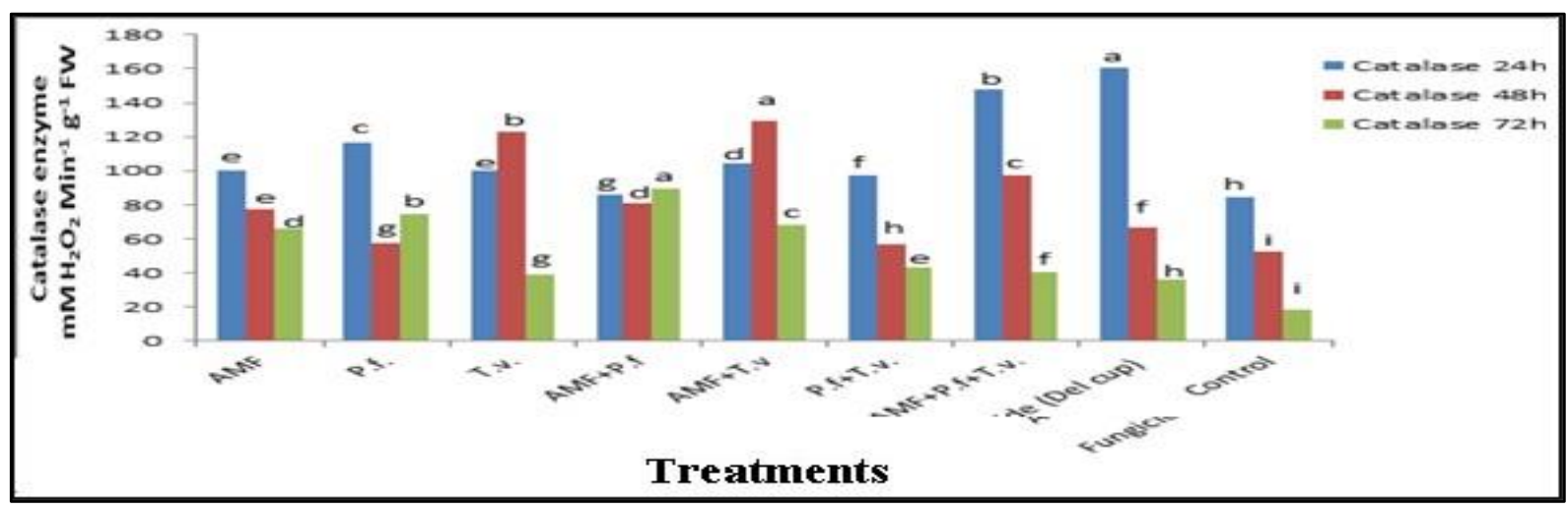

Fig (6): Changes in catalase activity in Giza 177 rice cultivar treated with three bio-control agents (AMF, P.f. and T.v.) and the fungicide Del-cup 


\section{DISCUSSION}

Farmers used to apply intensive chemical fertilizers and pesticides to get a good yield and quality of crops. Nowadays, peoples view towards using pesticides in agriculture has been changed as they are harmful to the environmental purity and human health (Pal and Gardener, 2006). Thus, number of carcinogenic pesticides has been removed from markets and the need to alternative solution becomes a necessity. One of these solutions is biological control, which has proved efficiency against many plant diseases (Abohatem et al., 2011 and Kumar et al., 2014). Many efficient bio- control agents with various mechanisms in plant diseases management have been applied. One of these mechanisms used to reduce the incidence of plant diseases is the induction of a systemic acquired resistance (Abo-Elyousr et al., 2008). As accumulation of pathogenesis-related PR proteins such as chitinase, â-13-glucanes, phenylalanine ammonia lyase, peroxidase, phenolics and phytoalexins, results in defense reaction (Kloepper et al., 2004).

To manage rice brown spot (RBS) disease in this study we used AMF in comparative study with Pseudomonas fluorescens and Trichoderma viride aiming to enlarge our biological base in controlling rice diseases. The in vitro antagonism test showed the efficiency of Pseudomonas fluorescens and Trichoderma viride in suppressing the pathogen growth of Bipolaris oryzae. T. viride showed faster growth rate than Bipolaris oryzae for space and nutrients. Thus, the pathogen growth is inhibited (Khalili et al., 2012). Angelica et al., 2001 assumed the ability of $T$. viride to produce amylase which aids in faster growth on PDA medium. Besides, producing extracellular cellulose and pectinase enzymes that hydrolyze other fungal cell walls. While P. fluorescens has antifungal secondary metabolites that are capable of lysing chitin, the most important component in fungal cell wall (Pandey and Chandel, 2014).

Under greenhouse conditions, the obtained results showed that after fungicide treatment, dressing seeds with the combinations of AMF + T.v. and AMF + P.f. + T.v., respectively were more efficient in RBS control followed by AMF alone and T.v. alone. These findings are in agreement with Morandi (1990) and Siqueira et al. (2002) who pointed out that the role of AMF in controlling plant diseases doesn't enclosed in increasing nutrient absorption only. But one of the factors that contribute to enhancing their role in controlling plant diseases is production of phenolic or secondary inhibitory compounds during their interaction with plants. Mart'inezMedina et al., 2009 found that combined inoculation of AMF with $T$. harzianum resulted in a general synergistic effect on disease control. Also, Gomathinayagam et al. (2012); Gaikwad and Balgude (2016) and Kumar et al. (2017) stated that Trichoderma spp. and Pseudomonas fluorescens are promising bioagents in rice diseases management (i.e., blast and brown spot). While Navaneetha et al., 2015 showed that Trichoderma spp. colonize and penetrate plant root tissues resulting in morphological and biochemical changes in the plant leading to Induced Systemic Resistance (ISR) responses to a wide range of pathogens and different environmental conditions. Also, (Heydari and Pessarakli, 2010 and Balgude et al., 2017) reported the effectiveness of $P$. fluorescens in controlling the rice brown spot and its ability to produce the antibiotic 2, 4diacetylphloroglucinol (DAPG) which may induce host defenses.

In vivo, at Sakha location, although the biocontrol agents alone or in combinations exceeded the fungicide treatment in reducing RBS disease incidence \%, the treatments of $\mathrm{AMF}, \mathrm{AMF}+$ P.f. +T.v. and T.v., respectively achieved the highest yield after the fungicide treatments. Similar results were found by Carvalho et al. (2015) when they suppressed rice leaf blast severity in vivo by three mycorrhizal extracts of Waitea circinata. They suggested the presence of phenolic compounds i.e., benzophenones. Besides a wide range of biological properties, including antifungal, antimicrobial, antioxidant and cytotoxic activities were found in the crude extract of Waitea circinata En07 (Wu et al. 2014). The treatments of AMF only, AMF + P.f. + T.v. and P.f. + T.v. followed the effect of Del cup fungicide in plant height. Sanni, 1976 also, observed better growth in mycorrhizal rice plants (Gigaspora gigentia) than the control. Similar results were obtained by Jangde (2013) who found that mycorrhizal rice plants were higher than the nonmycorrizal ones, achieving high productivity. Al-Taweil et al. (2009) stated that Trichoderma genus has a biocontrol activity as it has an ability to synthesize antagonistic compounds (proteins, enzymes and antibiotics) and growth promoting substances (vitamins, hormones and minerals). On the other hand, 
Voisard et al. (1989) reported that Pseudomonas fluorescens is known as a growth promoting rhizobacteria (PGPR) and plays a major role in inducing systemic resistance and control of plant pathogens.

At Gemmiza location, the treatments of $\mathrm{AMF}, \mathrm{AMF}+$ P.f. and T.v., respectively followed the fungicide treatment in reducing RBS disease incidence \% with good effect on other plant parameters. This is in accordance with Mousavi et al. (2014) who tested the ability of mycorrhizal fungus, Piriformospora indica, in inducing rice plant resistance against the blast disease and noticed an increase in the related defense genes, i.e., PR1b, LOX, NPR1 and WRKY85 in the treated plants comparing with the control. However, the treatments of T.v.; $\mathrm{AMF}+$ P.f. + T.v. and P.f. + T.v. exceeded the fungicide treatment in yield, Similar results were found by Gupta and Ali (1993) and Secilia and Bagya-raj (1994b) who reported a significant increase in the grain yield, by AMF colonization (Glomus intraradices \& G. fasciculatum) in wet land rice under both pot and field conditions. Also, Nielsen et al. (2002) and Picard (2008) mentioned that the antagonistic activity of Pseudomonas flouresens is due to the production of biosurfactant antibiotics and a number of antimicrobial compounds such as 2,4diacetylphloroglucinol (2,4-DAPG), phenazines (PHZ), pyrrolnitrin (PRN), pyoluteorin (PLT), hydrogen cyanide $(\mathrm{HCN})$. They all encourage the occurrence of defense reaction as a result of accumulation of PR proteins such as chitinase, â-13-glucanes, phenylalanine ammonia lyase, peroxidase, phenolics and phytoalexins (Kloepper et al., 1992). Data also was in accordance with Harish et al. (2007) who found Trichoderma spp. are effective in controlling rice brown spot disease and increasing rice plant growth. Also, Baker (1988) mentioned that Trichoderma species are able to colonize the root surface and rhizosphere from the treated seeds, protecting them from fungal diseases and stimulating plant growth and productivity.

Also, Bodker et al. (1998) and Cordier et al. (1998) reported that mycorrhizal fungi induced systemic resistance in pea and tomato plants infected with Aphanomyces euteiches and Phytophthora parasitics, respectively.

Pathogenesis-Related Proteins i.e., peroxidase (POX), polyphenoloxidase (PPO) and catalase were found to be induced in rice seedlings due to interactions between the tested bioagents and $B$. oryzae under the greenhouse. These enzymes were found to be involved in plant defenses against many pathogens (Abohatem et al., 2011; Mousavi et al., 2014). Peroxidase is known to have a role in the deposition of lignin and suberin in plant cellwalls (Baaziz and Saaidi, 1988 and Vieira et al., 2003). In this study, POX activity increased in $\mathrm{AMF}+$ P.f. + T.v., fungicide and P.f. + T.v. treatments after $24 \mathrm{~h}$ of inoculation then decreased after $48 \mathrm{~h}$ and raised again after $72 \mathrm{~h}$ as it occurred in AMF + T.v also. While, the other treatments raised in POX activity after $48 \mathrm{~h}$, then decreased after $72 \mathrm{~h}$ of infection. Thus, these results agreed with those obtained by Massoud and Kamel (2015) who showed an increase in POX activity in aliginated Macrophomina phaseolina with both of $\mathrm{AMF}$ and $T$. viride. Also, Vidhyasekaran, et al. (2001) observed increasing in lignification and peroxidase, PAL and 4CL activities in $P$. fluorescens treated plants in rice against Xanthomonas oryzae pv. oryzae.

Similar trends also were observed by Jaiti $e t$ al. (2007) as AMF induced plant protection against Fusarium oxysporum f.sp. albedinis by increasing peroxidase and polyphenol oxidase activities. These results were also was noticed in our work as PPO activity recorded the best in P.f. + T.v., AMF + P.f. + T.v., AMF and the fungicide treatments, after $24 \mathrm{~h}$ of infection. Then the activity was fluctuated in all treatments being higher than the check after $48 \mathrm{~h}$ and $72 \mathrm{~h}$. The fungicide was the only treatment that maintained stable till $72 \mathrm{~h}$ in PPO activity. Ozgonen et al., 2009 identified 12 different phenolic compounds in pepper plants by mycorrhiza fungus and Phytophthora capsici Leonian pathosystem, which were higher after 6 days after inoculation, but decreased on the 3rd and 9th days later. Catalases are one of the few enzymes that exhibit dual enzyme activity, they play a role of specific peroxidase and their function is to protect cells from toxic effects of hydrogen peroxide (Luhova, et al., 2003). Treatments of the fungicide, $\mathrm{AMF}+$ P.f. + T.v., P.f. and AMF + T.v. exhibited high values of catalase activity after $24 \mathrm{~h}$ of infection. Thus, induction of these enzymes inside rice seedlings showed the efficiency of the different biocontrol agents and interpreted their role in increasing the resistance. The present results encourage further trails of deep study to use AMF in the future as a new bio- control agent in rice ecosystem alone or in combinations with other common bio- control agents in controlling brown spot disease or other rice diseases. 


\section{CONCLUSION}

Rice brown spot disease is a world- wide distributed. It affects the grain quality and causes losses in yield. To provide a clean environment, bio- control agents were used in the form of seed dressing as alternative to fungicides. $\mathrm{AMF}$ is a promising bio-control agent in rice diseases management. AMF colonized rice roots, also $P$. fluorescens and $T$. viride inhibited the mycelial growth of Bipolaris oryzae resulting in deformation and lysis of the pathogen spores. AMF proved efficiency under greenhouse or field trails in disease management weather alone or in combinations with $P$. fluorescens and $T$. viride, in addition to increasing plant height and yield. The bioagent treatments exceeded Del cup fungicide in disease management at Sakha location in contrary to Gemmiza location. Pathogenesis related proteins (PR proteins) i.e., POX, PPO and catalase were induced so, plant resistance was enhanced against the pathogen.

\section{ACKNOWLEDGMENTS}

The authors would like to thank Prof.Dr. Massoud, O. N. Professor of microbiology, Soils, Water and Environment Research Institute, Agriculture Research Center, Giza, Egypt., for cooperation, and providing AMF inoculum and the strain of P. fluorescens to perform this study.

\section{COMPETING INTERESTS}

The authors declare that they have no competing interests.

\section{REFERENCES}

Abo-Elyousr A.M.K.; Hussein M.A.M.; Allam A.D.A. and Hassan A.H.M. 2008. Enhanced onion resistance against stemphylium leaf blight disease, caused by Stemphylium vesicarium, by di-potassium phosphate and benzothiadiazole treatments. Plant Pathol. J. 24 (2): 171-177.

Abohatem, M.; Chakrafi, F.; Jaiti, F.; Dihazi, A. and Baaziz, M. 2011. Arbuscular Mycorrhizal fungi limit incidence of Fusarium oxysporum f. sp. albedinis on Date palm seedlings by increasing nutrient contents, total phenols and peroxidase activities. The Open Horticulture Journal, 4: 10-16.
Addo, E.S.; Yasuda, M.; Lee, C.G.; Kanasugi, M.; Fujii, Y.; Omari, R.A.; Abebrese, S.O.; Bam, R.; Brempong, S.A.; Dastogeer, K.M.G. and Okazaki, S. 2020. Arbuscular mycorrhizal fungi associated with rice (Oryza sativa L.) in Ghana: Effect of regional locations and soil factors on diversity and community assembly. Agronomy, 10(4): 559.

Allam, A. I. and Hollis, J. P. 1972. Sulphide inhibition of oxidase in rice roots. Phytopathology, 62(3): 634-639.

Al-Taweil, H. I.; Bin Osman, M.; Abdul Hamid, A. and Yussof., W.M.W. 2009. Optimizing of Trichoderma viride cultivation in sub merged state fermentation can be a novel strategy in plant disease management. American Journal of Applied Sciences, 6 (7): 1284-1288.

Angelica, M.; Barbosa, G.; Rehn, K.G.; Menzes, M. and Mariano, R.R. 2001. Antagonism of Trichoderma sp on Cladosporium herbarum and their enzymatic characterization. Braz. J. Microbiol., 32:98-104.

Baaziz, M. and Saaidi, M. 1988. Preliminary identification of date palm cultivars by esterase isoenzymes and peroxidase activities. Can. J. Bot. 66: 89-93.

Baker, R. 1988. Trichoderma spp. as plantgrowth stimulants. Biotechnol. 7(2): 97-106.

Balgude Y.S.; Gaikwad A.P. and Kshirsagar C.R. 2017. Pseudomonas fluorescens, a potential bioagent for effective management of diseases in organic rice production. J. Rice Res. 10 (2):80-84.

Bodker, L.; Kjoller, R. and Rosendahl, S. 1998 Effect of phosphate and the arbuscular mycorrhizal fungus Glomus intraradices on disease severity of root rot in peas (Pisum sativum) caused by Aphanomyces euteiches. Mycorrhiza 8: 169 \pm 174 .

Carvalho, M.P.; Rodrigues, F.A.; Silveira, P.R.; Andrade, C.C.L.; Baroni, J.C.P.; Sa' Paye, H. and Junior, J.E.L. 2010. Rice resistance to brown spot mediated by nitrogen and potassium. J. Phytopathol. 158(3):160-166.

Carvalho, J.C.B.; Sousa, K.C.I.; Brito, D.C.; Chaibub, A.A.; Luzini, A.P.; Côrtes, M.V.C.B.; Filippi, M.C.C.; Kato, L.; Vaz, B.G.; Costa, H.B.; Romão, W. and Araújo, L.G. 2015. Biocontrol potential of Waitea circinata, an orchid mycorrhizal fungus, against the rice blast fungus Tropical Plant Pathology 40:151-159.

Chakrabarti, N.K. 2001. Epidemiology and disease management of brown spot of rice in 
India. In: Major fungal disease of rice: Recent Advances. Kluwer Academic Publishers. pp. 293-306.

Chandlee, M. and Scandalios, J.G. 1984. Analysis of variants affecting the catalase developmental program in maize scutellum. Theoretical and Applied Genetics, 9: 71-77.

Cordier, C.; Pozo, M.J.; Barea, J.M.; Gianinazzi, S. and Gianinazzi-Pearson, V. 1998. Cell defense responses associated with localized and systemic resistance to Phytophthora parasitica induced in tomato by an arbuscular mycorrhizal fungus. Mol Plant Microbe Interact 11: 1017-1028.

Devi, O.J. and Chhetry, G.K.N. 2013. Evaluation of antifungal properties of certain plants against Drechslera Oryzae causing brown leaf spot of rice in Manipur valley. Inter. J. Sci. and Res. 3 (5):1-3.

Duncan, B.D 1955. Multiple range and Multiple F-test. Biometrics, 11:1-42.

El-Gremi Sh.M.A. and Saleh, M.M. 2013. Controlling Sarocladium oryzae by antagonistic microorganisms on rice plants in Nile Delta- Egypt. J.Biol.Chem.Environ.Sci., 8 (4):63-74.

Gaikwad, A.P. and Balgude, Y.S. 2016. Induction of systemic resistance in rice against blast disease by bioagents and chemicals, J. Rice Research, 9 (2): 63-66.

Gomathinayagam, S.; Persaud, S.A. and Rekha, M. 2012. Comparative study of biological agents, Trichoderma harzianum and Trichoderma viride for controlling brown spot disease in rice. J. Biopest., 5: 28-32.

Gupta, N. and Ali, S.S. 1993. VAM inoculation for wetland rice. Mycorrhiza News 5:5-6.

Harish, S.; Saravavakumar, D.; Radjacommar, R.; Ebenezar, E.G. and Seetharaman, K. 2007. Use of plant extracts and biocontrol agents for the management of brown spot disease in rice. Biocontrol 53(3): 555-567.

Heydari, A. and Pessarakli, M. 2010. A review on biological control of fungal plant pathogens using microbial antagonists. J. Biol. Sci., 10: 273-290.

Hodge, A.; Gosling, P.; Goodlass, G. and Bending, G. 2003. Arbuscular Mycorrhizal Fungi (AMF) in organic farming, Defra Project OF 0333: 1-70.

Iqbal, M.F.; Hussain, M. and Waqar, M.Q. 2015. Evaluation of best fungicide for controlling brown leaf spot in transplanted rice. Int. J. Adv. Res. Biol.Sci. 2(7): 44-48.
IRRI. 2002. Standard Evaluation System for Rice (SES). International Rice Research Institute. Manila, Philippines. 56p.

Jaiti, F.; Meddich, A. and El Hadrami, I. 2007. Effectiveness of arbuscular mycorrhizal fungi in the protection of date palm (Phoenix dactylifera L.) against Bayoud disease. Physiol Mol Plant Pathol., 71 (4-6): 166-73.

Jangde, N. 2013. Mycorrhizal Study in Selected Cultivars of Rice. M.Sc. Thesis, The Rajendra Agricultural University, Bihar, Pusa. 111pp.

Khalili, Elham; Sadravi, M.; Naeimi, S. and Khosravi, V. 2012. Biological control of rice brown spot with naïve isolates of three Trichoderma species. Brazilian Journal of Microbiology: 297-305.

King, E.O.; Ward, M.K. and Raney, D.E. 1954. Two simple media for the demonstration of phycocyanin and fluorescin. J. Lab. Clin. Med. 44: 301-307.

Kloepper, J.W.; Ryu, C.-M. and Zhang, S. 2004. Induced systemic resistance and promotion of plant growth by Bacillus spp. Phytopathology, 94:1259-1266.

Kloepper, J.W.; Tuzun, S. and Kuc, J.A. 1992. Proposed definitions related to induced disease resistance. Biocontrol Science and Technology 2: 349-351.

Kumar, S.; Abhilasha, A.L.; Kumar, N.; Jaiswal, S.; Kumar, H.; Kumar, A. and Kumar, M. 2017. Effect of bio control agents and botanicals against Blast of Paddy caused by Pyricularia oryzae. International Journal of Chemical Studies; 5(1): 314-318.

Kumar, R.; Kumari, A.; Zacharia, S. and Tiwari, S. 2014. Efficacy of Trichoderma viride and Pseudomonas fluorescens against Paddy Brown Spot In- Situ. Trends in Biosciences 7(14): 1712-1716.

Luhova, L.; Lebeda, A.; Hedererova, D. and Pec, P. 2003. Activities of amine oxidase, peroxidase and catalase in seedlings of Pisum sativum L. under different light conditions. Plant soil and Environ., 49(4):151-157.

Mart'inez-Medina, A.; Pascual, J.A.; Lloret, E. and Roldan, A. 2009. Interactions between arbuscular mycorrhizal fungi and Trichoderma harzianum and their effects on Fusarium wilt in melon plants grown in seedling nurseries. J. Sci. Food Agric. (89): 1843-1850.

Massoud, O.N. 2005. Microbiological and chemical evaluation of compost and its application in organic farming. Ph.D. thesis, 
Dep. of Biology, Fac. Sci. Minufiya University, pp 179.

Massoud, O. N. and Kamel, S. M. 2015. The inhibitory effects of free and encapsulated arbuscular mycorrhizal fungi and Trichoderma viride against charcoal rot (Macrophomina phaseolina) on common bean (Phaseolus vulgaris L.). Egyptian Journal of Biological Pest Control, 25(2): 489-497.

Maxwell, D.P. and Bateman, D.F. 1967. Change in the activities of some oxidases in extracts of Rhizoctonia infected bean hypocotyls in relation to lesion maturation. Phytopathology, 57: 132-136.

Morandi, D. 1990. Effect of endomycorrhizal infection and biocides on phytoalexin accumulation in soybean roots. Agric Ecosyst Environ 29: 303-305.

Mousavi, S.H.; Babaeezad, V.; Sharifnabi, B.; Tajic Ghanbari, M. A.; Massah, A. and Alavi, S. M. 2014. Induction of blast disease resistance in rice plants by endophyte fungus Piriformospora indica Iran. J. Plant Path., 50(3): 127-129.

Muhanna, N.A.S.; Essa, T.A.; El-Gamal, M.A.H. and Kamel, S.M. 2016. Efficacy of free and formulated arbuscular mycorrhiza, Trichoderma viride and Pseudomonas fluorescens on controlling tomato root rot diseases. Egyptian Journal of Biological Pest Control, 26(3): 477-486.

Navaneetha, T.; Prasad, R.D. and Venkateswar, R. L. 2015. Liquid Formulation of Trichoderma species for management of Gray mold in Castor (Ricinus communis L.) and Alternariaster leaf blight in Sunflower (Helianthus annuиs L.). $\mathrm{J}$ Biofertil. Biopestici, 6:1.

Nielsen, T.H.; Sorensen, D.; Tobiasen, C.; Andersen, J.B.; Christophersen, C.; Givskov, M.; Sorensen, J. 2002. Antibiotic and biosurfactant properties of cyclic lipopeptides produced by fluorescent Pseudomonas spp. from the sugar beet rhizosphere. Appl. Environ. Microb. 68:3416-3423.

Nisikado, Y.; Miyake, C. (1922). Studies on the Helminthosporiose of the Rice plant. Berichte des Ohara Instituts fur Landwirtschaftliche Biologie, Okayama Universitat 1922. 2(2): 133-194.

Ou, S.H. 1985. Rice disease $\left(2^{\text {nd }}\right.$ ed.). Kew: Commonwealth Mycological Institute. 380 pp.
Ozgonen, H.; Yardimci, N. and Kiliç, H.C. 2009. Induction of phenolic compounds and pathogenesis-related proteins by mycorrhizal fungal inoculations against Phytophthora capsici Leonian in Pepper. Pakistan Journal of Biological Sciences 12(17):1181-1187.

Padmanabhan, S. Y. 1973. The Great Bengal Famine. Annu. Rev. of Phytopathol., 11: 1126.

Pal, K.K. and Gardener, B.M. 2006. Biological Control of Plant Pathogens. The Plant Health Instructor DOI: 10.1094/PHI-A-2006-111702.

Pandey, A.K. and Chandel, S.C.R. 2014. Efficacy of Pseudomonas as biocontrol agent against plant pathogenic fungi. Int. J. Curr. Microbiol. App. Sci., 3(11): 493-500.

Picard, C. 2008. Genotypic and phenotypic diversity in populations of plant-probiotic Pseudomonas spp. colonizing roots. Naturwisenschaften, 95: 1-16.

Rashed, R.; Hossain, M.; Islam, M. R.; Akter, N; Mazumder, A.R. and Zakaria, M. 2002. Effect of brown spot on the yield and yield contributing characters of different hybrid varieties/ lines of Boro rice. Pakistan, J.Plant Pathology 1(2-4):58-60.

Saleh, M.M. 2002. Biological control of some soil borne diseases on corn. M.Sc. Thesis. Fac. of Agric., Tanta Univ., Egypt, pp 119.

Saleh, M.M. 2012. Studies on the sheath rot disease of rice. Ph.D. Thesis. Fac. of Agric., Kafrelsheikh Univ., Egypt, pp 147.

Sanni, S.O. 1976. Vescular-arbuscular mycorrhiza in some nigerian soils: The effect of Gigaspora gigantean on the growth of rice. New Phytol. 77: 673-674.

Secilia, J. and Bagyaraj, D.J. 1994. Evaluation and first-year field testing of efficient vesicular arbuscular mycorrhizal fungi for inoculation of wetland rice seedlings. World Journal of Microbiology and Biotechnology 10: 381-384.

Siqueira, J.O.; Lambais, M.R. and Sturrmer, S.L. 2002. Fungos micorrízicos arbusculares: características, associação simbiótica e aplicação na agricultura. Biotecnol Cienc Desenv 25: 12-21.

Vidhyasekaran, R.; Kamala, N.; Ramanathan, A.; Rajappan, K.; Paranidharan, V. and Velazhahan, R. 2001. Induction of systemic resistance by Pseudomonas fluorescens Pfl against Xanthomonas oryzae pv. oryzae in rice leaves. Phytoparasitica 29(2):155-166.

Vieira, Dos Santos C.; Letousey, P.; Delavault, P. and Thalouarn, P. 2003. Defense gene 
expression analysis of Arabidopsis thaliana parasitized by Orobanche ramosa. Phytopathol., 93: 451-7.

Vierheilig, H.; Coughlan, A.P.; Wyss, U. and Piche, Y. 1998. Ink and vinegar, a simple staining technique for ArbuscularMycorrhizal Fungi. Applied and Environmental Microbiology, 64 (12): 50045007.
Voisard, C.; Keel, C.; Haas, D. and Defago, G. 1989. Cyanide production by Pseudomonas fluorescens helps suppress black root rot of tobacco under gnotobiotic conditions. EMBO J.; 8:351-358.

Wu, S.B.; Long, C. and Kennelly, E.J. 2014. Structural diversity and bioactivities of natural benzophenones. Nat Prod Rep 31:1158-1174. 